\title{
Does Political Legitimacy Matter for Policy Capacity?
}

\author{
Honorata Mazepus \\ All men think justice to be a sort of equality... But there still remains a question: \\ equality of what? The question is an aporia and calls for political thought.
}

(Aristotle in Rosanvallon 2006, p. 61)

\subsection{INTRODUCTION}

Legitimacy is an important quality of political authorities (both individuals and institutions), because it indicates a recognition of the authorities' right to rule. Moreover, this right to rule is typically recognized on normative grounds and therefore constitutes an important resource of power beside coercion and incentives (Beetham 2006, pp. 107-108). If political actors are perceived as appropriate and trustworthy, citizens may voluntarily transfer decision-making power to them. Therefore, no political regime or authority benefits from appearing illegitimate. This is because coercion and simple distribution of rewards is a costly way of making people comply with laws and policies, and because it does not generate diffuse support for a political system or authority (Easton 1965, p. 278). Relying on legitimacy, at least in principle, makes ruling easier and cheaper. The importance of legitimacy extends beyond political systems, regimes and authorities: legitimacy is also a valuable characteristic of policies. Moreover, the legitimacy of political systems and authorities can affect the legitimacy of policies, and vice versa.

Firstly, if institutions are not recognized as (morally) appropriate, the authorities who draw their right to rule from these institutions will most likely not be recognized as appropriate either. Furthermore, if the authorities have low legitimacy, the policies that they implement will not 
meet with high social approval (at least initially). Conversely, if policies repetitively do not deliver the desired outcomes, and the process of policymaking is not considered (morally) appropriate, the legitimacy of political authorities and the entire political system will be undermined.

A growing body of literature shows that across societies, legitimacy increases compliance with court rulings, laws, and policies, and raises satisfaction with distribution of outcomes. Hence, political legitimacy seems to be an important component of policy capacity. As a result, research about how to gain legitimacy and what means can be used to increase legitimacy (normative approval) of particular decisions, laws, or authorities should attract interest from both political scientists and policy scholars. Although more research is needed to provide increasingly fine-tuned answers, one factor that seems to consistently contribute to legitimacy (and as a consequence, to compliance) is the fairness of political authorities. Countering the assumption that successful policy has to entail an increased distribution of goods and services to people, evidence suggests that people are not only concerned about their personal gains; on the contrary, they care about a fair process of decision-making, including transparency, stakeholder voice, and opportunity for engagement in policy development. Procedural considerations might outweigh the importance of personally favourable outcomes or, in the realm of public policy, even effective and efficient policy (Wallner 2008). This chapter discusses evidence from social psychology, political science, and policy studies to suggest that increasing legitimacy through procedural fairness might be key to successful policymaking.

\subsection{Legitimacy and Its Dimensions}

There are multiple definitions of legitimacy. Some scholars follow a Weberian definition (Weber 1978, p. 213) and treat it as a belief (Dahl 1956, p. 46; Fraser 1974; Linz 1988), others see it as a quality of a regime (Merelman 1966, p. 548), as "the compatibility of the results of governmental output with the value patterns of the relevant systems" (Stillman 1974, p. 42), or as "institutional loyalty" (Gibson et al. 2005, pp. 188-189). Philosophers refer to legitimacy as "the complex moral right to impose decisions on others" (Simmons 1999, p. 746). All these understandings of legitimacy suggest that there are at least two main components of the definition: legitimacy is about the recognition of the 
right to rule and it is based on an assessment of the moral standards followed by authorities.

The scholarly debate within political science has emphasized the multi-dimensional nature of the concept (Alagappa 1995, pp. 11-30; Beetham 1991; Easton 1975; Friedrich 1963, p. 234; Scharpf 1998; Stillman 1974, p. 39). There is, however, no consensus on how many dimensions the concept of legitimacy has and what these dimensions encompass. For example, Alagappa (1995) names four dimensions (or elements) of legitimacy: shared values and norms, conformity with established rules, proper use of power, and consent of the governed. Booth and Seligson (2009, pp. 547-548) recognize seven dimensions of legitimacy: existence of political community; support for core regime principles; evaluation of regime performance; system support; support for regime institutions; support for local government; and support for political actors. The most concise list of the various dimensions of legitimacy was developed by Scharpf (2003) and Schmidt (2013), who distinguished between input, throughput, and output dimensions. Although this three dimensional approach is not without problems, it might be very useful in the context of policymaking capacity.

The distinction between input, output, and throughput legitimacy (Scharpf 1998, 2003; Schmidt 2013) has its roots in Easton's political system analysis (1957, p. 384). ${ }^{1}$ Input legitimacy is concerned with the conditions that a political system provides to link authorities' actions and the 'authentic preferences of citizens' (Scharpf 1997, p. 19). Because of the input, authorities reflect (or ought to reflect) the values, norms, and needs present in society. Throughput legitimacy is concerned with the quality of the governance process (Schmidt 2013, p. 2), and output legitimacy is about the effectiveness of authorities in achieving common goals and solving common problems (Scharpf 2003). In short, input is about governing by the people (usually referring to representation through a vote in elections), throughput is about governing with the people (Schmidt 2013, p. 3), and output is about governing for the people. This classification of dimensions of legitimacy seems suitable not only when thinking about political systems, but also in the context of the legitimacy of public policies. Specifically, the process of policymaking demands knowledge about what is needed and expected (input), it is conducted in a certain way (throughput) and it delivers particular outcomes (output). 
Following the logic of these three dimensions of legitimacy, if citizens have a say in who rules over them, how, and why (i.e. to achieve what goals), they might be more willing to grant legitimacy to political authorities and institutions. A large amount of legitimacy encourages citizens to cooperate with authorities and institutions and generate economic, social, and political results. In modern states, the benefits of legitimacy may include citizens' compliance with laws, voting, payment of taxes, participation in solving community problems, military service, and defense of one's country (Beetham 2006; Booth and Seligson 2005, 2009; Levi et al. 2009; Sunshine and Tyler 2003). Therefore, finding a way to increase input and throughput legitimacy might be as important as increasing output legitimacy. The common normative considerations found to influence the attribution of legitimacy to political authorities, policies, and decisions are concerned with procedural and distributive fairness.

\subsection{What Do People Care About? The Role of Procedural and Distributive Fairness}

It used to be a widespread notion in political science that people "generally care about ends not means; they judge government by results and are ignorant of or indifferent about the methods by which the results were obtained" (Popkin 1994, p. 99). As summarized by Hibbing and Theiss-Morse (2008, p. 123), "To understand perceptions of legitimacy, it was only necessary to measure the gap between an individual's policy preference and the actual policy output of the government." That is, if legitimacy is a function of outcomes, then the amount of legitimacy attributed to an authority is equal to the difference between the policy outcome and the policy preference of an individual. If the policy preference is equal to the outcome, then the authority is perceived as completely legitimate. The larger the gap between policy preference and outcome, the lower the perceived legitimacy of the authority. This suggests that scholars and policymakers should focus on one very clear policymaking aspect: providing favourable outcomes to people. However, there is growing evidence that even when controlling for the outcome that individuals receive as an effect of a policy or decision, the fair treatment of citizens by authorities positively influences the authorities' legitimacy (Lind and Tyler 1988; Sunshine and Tyler 2003; Tyler 2000, 
2001; Tyler and Folger 1980). Therefore, while providing favourable outcomes is a crucial task of political authorities (Dogan 1992; Lipset 1959, p. 77) input and throughput legitimacy (including normative considerations about the governing process) are also relevant. There are two ways in which fair treatment seems to be linked to legitimacy: fairness of processes (procedural fairness) and fairness of outcomes (distributive fairness) (Van den Bos et al. 1997).

Procedural fairness refers to people's evaluations of procedures used by authorities as fair or unfair, as right or wrong. In line with Leventhal (1980, p. 5), the procedural fairness rule is defined as 'an individual's belief that allocative procedures which satisfy certain criteria are fair and appropriate'. This definition implies that one of the goals of using fair procedures is to make sure that the citizens trust they have received a fair outcome (not necessarily a favourable one).

The body of research on procedural fairness has been growing in the past couple of decades within the field of social psychology (see Tyler 2006). A number of studies show that the legitimacy of laws and of the police increases when people experience fairness of procedures (Sunshine and Tyler, 2003; Tyler 2001; Tyler and Caine 1981). Tyler and Caine (1981, p. 643) show that satisfaction with leaders was also influenced by judgments about fairness of procedures for allocating benefits, regardless of the achieved outcomes.

Fairness of procedures usually refers to the fairness of decision-making processes used by authorities. A fair process is comprised of several specific procedures: providing opportunity to voice people's opinions (voice/public deliberation/participation), considerations of all the relevant information, following established formal rules to guide the decision-making process, maintaining neutrality and consistency of authorities across people and cases (unbiased and impartial decisionmaking), and treating citizens with dignity and respect (Leventhal 1980; Peter 2009; Thibaut and Walker 1975; Tyler 2000; Tyler and Rasinski 1991; Tyler et al. 1985). The importance of different criteria of procedural fairness varies depending on the issue, dispute, context, and institution under evaluation (Tyler 1988, p. 107).

Elaborating on the principle of giving voice to citizens, the role of deliberation processes has been emphasized in political science discussions of democracy and communication science discussions of information processing by citizens (Ackerman and Fishkin 2004, Bohman 1997; Dryzek 2009; Dryzek 2010; Gutmann and Thompson 2009; Habermas 
1996; Manin et al. 1987; Miller 1992a). Deliberation is 'a process of careful and informed reflection on facts and opinions, generally leading to a judgment on the matter at hand' (King 2003, p. 25). This process involves citizens in a discussion and provides them with an opportunity to voice their opinions and inquire about the issues that are decided on by the authorities. Such deliberative practices are part of procedural fairness and overlap with the throughput dimension of legitimacy (governing with the people).

A question that is currently less well researched is which specific procedures, under which conditions, lead to higher legitimacy of particular authorities or policies (Van de Walle and Bouckaert 2003). For example, while voice is an important aspect of procedural fairness, it does not seem to have desirable effects in all circumstances. It may be that there are no positive effects of providing people with an opportunity to voice their interests, if they do not see evidence that their voice was included in decision-making (Hibbing and Theiss-Morse 2008, pp. 16-17). Also, not all policy areas might require deliberation and people's involvement might not always lead to increases in legitimacy (see, for example, the case of technology policy in Abels 2007). Moreover, it is possible that people disagree on what is a fair process (Lind et al. 1990) and on which aspects of participation in decision-making deliberation are important (Krueger et al. 2001). Also, the evidence on the durability of the effect of deliberation and the impact of information and misinformation on citizen political (and policy) preferences is mixed and more studies in this area are needed (Kuklinski et al. 2000; Luskin et al. 2002; Pasek et al. 2015; Schueler and West 2015). Other studies suggest that the effects of procedural fairness differ depending on the presence or absence of the second main factor influencing legitimacy: distributive fairness (Van den Bos et al. 1997; Van den Bos et al. 1998).

Following the principle of distributive fairness, people are expected to "be more willing to give power to legal authorities when they feel that those authorities deliver outcomes fairly to people" (Sunshine and Tyler 2003). Distributive fairness can be seen also as a part of the idea of common good-"the conviction that there is something called the interest of the realm, the public, common, or national interest, the general good and public welfare, or the good of the tribe, of 'our people" (Easton 1965 , p. 312). According to Easton, political authorities are supposed to promote and contribute to the common good and their failure to do so will diminish the perceived legitimacy of a regime. Distributive fairness 
refers to one aspect of the common good, namely the distribution of resources in a manner that helps the society as a whole. Distributive fairness can be based on different principles depending on the information available to the people, the type of group in which the distribution takes place, the particular situation, and the socio-economic status of an individual. The main principles on which distributive fairness can be based are equality, desert (or equity), and need (DeScioli et al. 2014; Miller 1992b).

Distributive fairness is connected to Scharpf's ideas about output legitimacy-governing for the people. One of the main goals of government is to achieve some sort of common interest. If the pursuit of the "common purposes and dealing with common problems that are beyond the reach of individuals and families acting on their own" (Scharpf 2003, p. 4) is positively evaluated by citizens, the legitimacy of an institution increases. Hence, if the goods and services are distributed in a way that serves the communal interest (rather than individual interests) and citizens do not experience strong relative deprivation (Gurr 1970), then the government will be appreciated and will enjoy higher legitimacy. Distributive fairness is inherently linked with individuals' perceptions of their situation in comparison to the situation of others belonging to the same community. Reflection on this relative situation might increase legitimacy. This is how distributive fairness (contributing to output legitimacy) could be linked with procedural fairness (contributing to input and throughput legitimacy).

If people are informed about how allocative decisions are taken (transparency and information provision), are able to voice their interests, experience equal treatment (or treatment according to fair rules that apply to everybody), and perceive no unjustified discrimination, they should be more likely to perceive the distribution of outcomes as fair. As in the case of procedural fairness research (Hibbing and Theiss-Morse 2008), social psychological research provides insights into how the perceptions of fair distribution are shaped. Specifically, evolutionary psychology provides evidence of how people think about resource distribution principles and social welfare provision (Bøggild and Petersen 2016; DeScioli et al. 2014; Petersen 2012). Although we know something about the mechanisms of fairness, the link between procedural fairness and distributive fairness is still underexplored. Further research is needed to tell how the two are related and how they interact in the context of particular policies. 


\subsection{Policy Capacity, Legitimacy, and Procedural FAIRNESS}

To recognize the importance of legitimacy for policy capacity, policy capacity has to be understood in broad terms and seen in the context of administrative and state capacity (Howlett 2015, p. 173; Painter and Pierre 2005 , p. 2). This means that policy capacity does not concern only the competences and skills of policymaking and the resources needed to execute policies (Peters 1996), but also the way the administrative human resources operate to achieve the policy goals (i.e., administrative capacity) and the approval of these policies by society (i.e., state capacity) (Painter and Pierre 2005, p. 2). The way the human resources operate is limited by the competences, skills, and resources at the administration's disposal. At the same time, the way the human resources operate affects the extent to which the society approves the policies (see Fig. 10.1). The policy formation process can be evaluated in terms of, for example, legality, transparency, cost efficiency, and the involvement of the stakeholders and broader public at the stages of consultation and decision-making. How the policy is made thus influences the shape of the policy (what kind of outcomes are delivered), but also the perception of its fairness, as the public and especially those affected by the policy will formulate the normative judgment about the policy. These normative judgments (the judgments about the procedural and distributive fairness of the policy) will in turn affect the legitimacy of the policy (its normative approval).

Moreover, as Fig. 10.1 shows, the last aspect of policy capacity, the evaluation of the policy, is affected by the level of legitimacy (normative approval) and the satisfaction with the outcome (instrumental approval). Therefore, policy capacity can be increased not only by providing desirable (material) results, but also by using fair procedures. By using fair procedures, policies, just like political actors, are likely to increase in legitimacy. Higher legitimacy, in turn, is likely to lead to better evaluation of and higher compliance with policies.

Apart from research in social psychology and political science, there seems to be growing evidence in the field of policy studies that fairness and fair procedures are relevant specifically for policymaking. One example is a study of very similar education policies implemented in radically different ways - either with the stakeholders' and popular support or without it (Wallner 2008). The policy process that included the stakeholders was more successful in achieving policy goals. Moreover, 


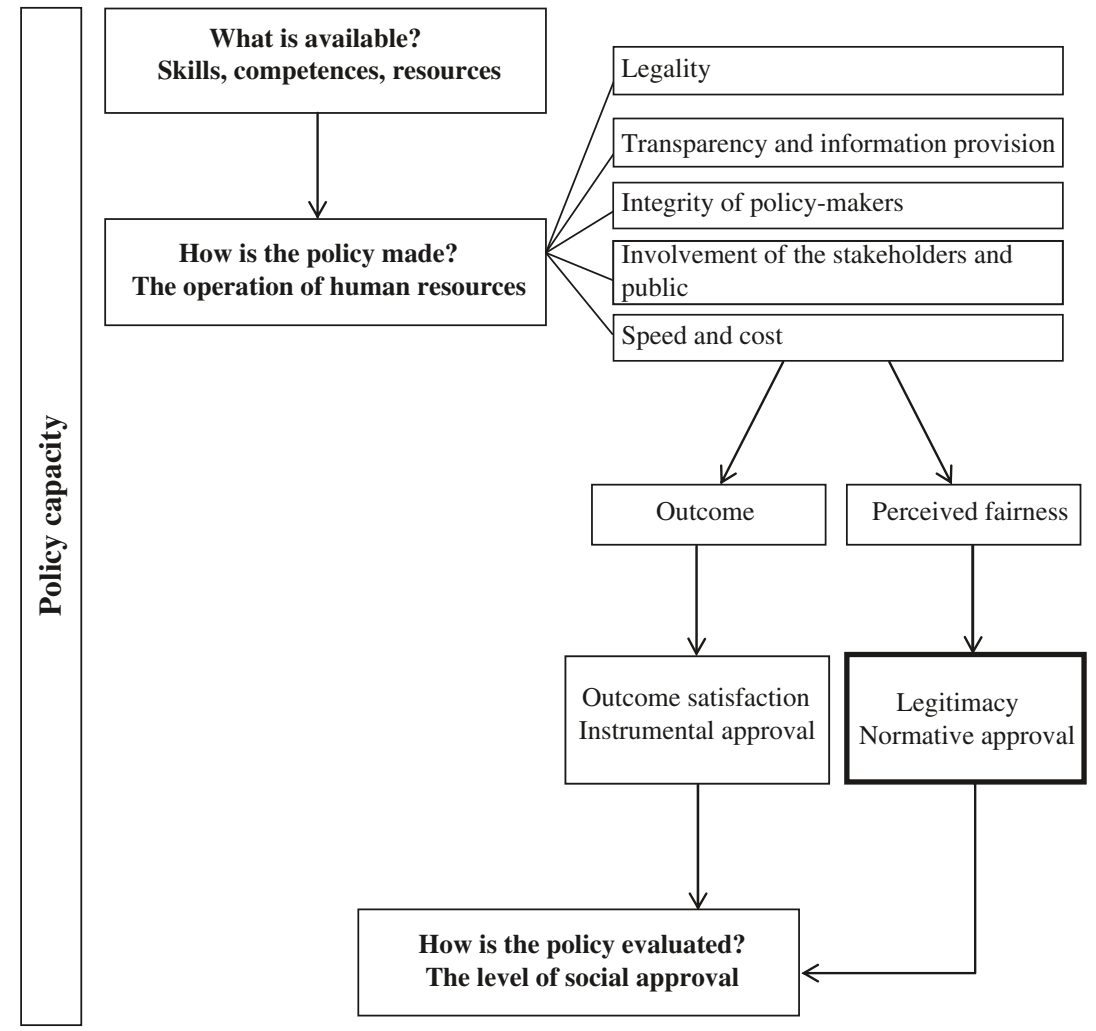

Fig. 10.1 Policy capacity and the role of legitimacy

procedural fairness (participation, transparency, access to relevant information, neutrality) seems crucial to long-term effectiveness of public policies. Other studies on the local/organizational level have shown that the acceptability of decisions that negatively affected people, such as price rises or salary cuts, is higher when people are involved in discussions, are informed, and agree with the reasons for these decisions (see Dolan et al. 2007). Dolan et al. (2007) have begun to illuminate what procedures citizens expect in the context of health care policies. As mentioned above, different policy domains may require different ways of policymaking. For example, the speed of policymaking may be prioritized by citizens in the case of a virus outbreak, whereas long social, expert, and 
stakeholder consultations could be prioritized in the case of far-reaching reforms in the education or healthcare sector. The domain, particular issue, scope, importance, and potential impact of a policy under consideration might call for different socially approved and desirable means of policymaking. What in one case could be considered a fair process of arriving at a policy decision may, in another case, be seen as irresponsible behavior of administrators. Therefore more comparative research is needed to understand the relation between different policy domains, the way the policy is made, and perceptions of fairness and legitimacy.

In summary, policy studies would benefit from research on procedural fairness (input and throughput legitimacy) and how it relates to distributive fairness (output legitimacy). Further research might seek systematic empirical evidence on the processes that link specific procedures, legitimacy, and the success of particular policies.

\section{Note}

1. Easton also distinguished three elements of political systems: input (demands and support of the governed), processes within a political system, and outputs (policy decisions).

\section{REFERENCES}

Abels, G. (2007). Citizen involvement in public policy-making: Does it improve democratic legitimacy and accountability? The case of pTA. Interdisciplinary Information Sciences, 13(1), 103-116.

Ackerman, B., \& Fishkin, J. S. (2004). Deliberation day. New Haven: Yale University Press.

Alagappa, M. (1995). Political legitimacy in Southeast Asia: The quest for moral authority. Stanford, CA: Stanford University Press.

Beetham, D. (1991). The legitimation of power. Houndmills: Macmillan.

Beetham, D. (2006). Political legitimacy. In K. Nash \& A. Scott (Eds.), The blackwell companion to political sociology. Oxford: Blackwell.

Bøggild, T., \& Petersen, M. B. (2016). The evolved functions of procedural fairness: An adaptation for politics. In The evolution of morality (pp. 247-276). Springer. doi:10.1007/978-3-319-19671-8_12.

Bohman, J. (1997). Deliberative democracy: Essays on reason and politics. Cambridge, MA: MIT Press.

Booth, J. A., \& Seligson, M. A. (2005). Political legitimacy and participation in Costa Rica: Evidence of arena shopping. Political Research Quarterly, 58(4), 537-550. 
Booth, J. A., \& Seligson, M. A. (2009). The legitimacy puzzle in Latin America: Political support and democracy in eight nations. New York: Cambridge University Press.

Dahl, R. A. (1956). A preface to democratic theory. Chicago: University of Chicago Press.

DeScioli, P., Massenkoff, M., Shaw, A., Petersen, M. B., \& Kurzban, R. (2014). Equity or equality? Moral judgments follow the money. Proceedings of the Royal Society of London B: Biological Sciences, 281(1797), 2014-2112.

Dogan, M. (1992). Conceptions of legitimacy. In M. Hawkesworth \& M. Kogan (Eds.), Encyclopedia of government and politics. London: Routledge.

Dolan, P., Edlin, R., Tsuchiya, A., \& Wailoo, A. (2007). It ain't what you do, it's the way that you do it: Characteristics of procedural justice and their importance in social decision-making. Journal of Economic Behavior o Organization, 64(1), 157-170.

Dryzek, J. S. (2009). Democratization as deliberative capacity building. Comparative Political Studies, 42(11), 1379-1402.

Dryzek, J. S. (2010). Foundations and frontiers of deliberative governance. Oxford: Oxford University Press.

Easton, D. (1957). An approach to the analysis of political systems. World Politics, 9(3), 383-400.

Easton, D. (1965). A systems analysis of political life. New York: Wiley.

Easton, D. (1975). A re-assessment of the concept of political support. British Journal of Political Science, 5(4), 435-457.

Fraser, J. (1974). Validating a measure of national political legitimacy. American Journal of Political Science, 18(1), 117-134.

Friedrich, C. J. (1963). Man and his government: An empirical theory of politics. New York: McGraw-Hill.

Gibson, J. L., Caldeira, G. A., \& Spence, L. K. (2005). Why do people accept public policies they oppose? Testing legitimacy theory with a survey-based experiment. Political Research Quarterly, 58(2), 187-201. doi:10.2307/3595622.

Gurr, T. R. (1970). Why men rebel. Princeton, NJ: Princeton University Press.

Gutmann, A., \& Thompson, D. (2009). Why deliberative democracy? Princeton: Princeton University Press.

Habermas, J. (1996). Between facts and norms: Contributions to a discourse theory of law and democracy (Vol. 76). Cambridge, MA: MIT Press.

Hibbing, J. R., \& Theiss-Morse, E. (2008). Voice, validation, and legitimacy. In Sullivan, B., Snyder, M. \& J. L. Sullivan (Eds.) Cooperation: The political psychology of effective human interaction (pp. 123-142). Malden, MA: Blackwell.

Howlett, M. (2015). Policy analytical capacity: The supply and demand for policy analysis in government. Policy and Society, 34(3-4), 173-182. doi:10.1016/j.polsoc.2015.09.002. 
King, L. A. (2003). Deliberation, legitimacy, and multilateral democracy. Governance, 16(1), 23-50.

Krueger, R., Tuler, S., \& Webler, T. (2001). What is a good public participation process? Five perspectives from the public. Environmental Management, 27(3), 435-450. doi:10.1007/s002670010160.

Kuklinski, J. H., Quirk, P. J., Jerit, J., Schwieder, D., \& Rich, R. F. (2000). Misinformation and the currency of democratic citizenship. The Journal of Politics, 62(3), 790-816.

Leventhal, G. S. (1980). What should be done with equity theory? Springer. doi:10.1007/978-1-4613-3087-5_2.

Levi, M., Sacks, A., \& Tyler, T. (2009). Conceptualizing legitimacy, measuring legitimating beliefs. American Behavioral Scientist, 53(3), 354-375. doi:10.1177/0002764209338797.

Lind, E. A., Kanfer, R., \& Earley, P. C. (1990). Voice, control, and procedural justice: Instrumental and noninstrumental concerns in fairness judgments. Journal of Personality and Social Psychology, 59(5), 952-959. doi:10.1037/0022-3514.59.5.952.

Lind, E. A., \& Tyler, T. R. (1988). The social psychology of procedural justice. New York: Plenum press.

Linz, J. J. (1988). Legitimacy of democracy and the socioeconomic system. In M. Dogan (Ed.) Comparing pluralist democracies (pp. 65-113). Boulder: Westview Press.

Lipset, S. M. (1959). Political man, the social basis of politics. New York: Doubleday.

Luskin, R. C., Fishkin, J. S., \& Jowell, R. (2002). Considered opinions: Deliberative polling in britain. British Journal of Political Science, 32(03), 455-487.

Manin, B., Stein, E., \& Mansbridge, J. (1987). On legitimacy and political deliberation. Political Theory, 15(3), 338-368. doi:10.2307/191208.

Merelman, R. M. (1966). Learning and legitimacy. The American Political Science Review, 60(3), 548-561.

Miller, D. (1992a). Deliberative democracy and social choice. Political Studies, 40, 54-67. doi:10.1111/j.1467-9248.1992.tb01812.x.

Miller, D. (1992b). Distributive justice: What the people think. Ethics, 102(3), $555-593$.

Painter, M., \& Pierre, J. (2005). Unpacking policy capacity: Issues and themes. In M. Painter \& J. Pierre (Eds.), Challenges to state policy capacity (pp. 1-18). Palgrave Macmillan. doi:10.1057/9780230524194_1.

Pasek, J., Sood, G., \& Krosnick, J. A. (2015). Misinformed about the affordable care act? Leveraging certainty to assess the prevalence of misperceptions. Journal of Communication, 65(4), 660-673.

Peter, F. (2009). Democratic legitimacy. New York: Routledge. 
Peters, B. G. (1996). The policy capacity of government. Canadian Centre for Management Development.

Petersen, M. B. (2012). Social welfare as small-scale help: Evolutionary psychology and the deservingness heuristic. American Journal of Political Science, 56(1), 1-16.

Popkin, S. L. (1994). The reasoning voter: Communication and persuasion in presidential campaigns. Chicago: University of Chicago Press.

Rosanvallon, P. (2006). Democracy past and future. New York: Columbia University Press.

Scharpf, F. (1997). Economic integration, democracy and the welfare state. Journal of European Public Policy, 4(1), 18-36.

Scharpf, F. (1998). Interdependence and democratic legitimation. (MPIfG Working Paper, 98(2)). Retrieved from http://www.econstor.eu/handle/10419/41664.

Scharpf, F. (2003). Problem-solving effectiveness and democratic accountability in the EU. (MPIfG working paper). Retrieved from http://hdl.handle. net/10419/41689.

Schmidt, V. A. (2013). Democracy and legitimacy in the European Union Revisited: Input, output and 'throughput'. Political Studies, 61(1), 1-21. doi:10.1111/j.1467-9248.2012.00962.x.

Schueler, B. E., \& West, M. R. (2015). Sticker shock how information affects citizen support for public school funding. Public Opinion Quarterly, nfv047.

Simmons, A. J. (1999). Justification and legitimacy. Ethics, 109(4), 739-771.

Stillman, P. G. (1974). The concept of legitimacy. Polity, 7(1), 32-56. doi: $10.2307 / 3234268$.

Sunshine, J., \& Tyler, T. R. (2003). The role of procedural justice and legitimacy in shaping public support for policing. Law \& Society Review, 37(3), 513-548.

Thibaut, J. W., \& Walker, L. (1975). Procedural justice: A psychological analysis. New York: Lawrence Erlbaum Associates Hillsdale.

Tyler, T. R. (1988). What is procedural justice-criteria used by citizens to assess the fairness of legal procedures. Law and Society Review, 22, 103.

Tyler, T. R. (2000). Social justice: Outcome and procedure. International Journal of Psychology, 35(2), 117-125. doi:10.1080/002075900399411.

Tyler, T. R. (2001). The legitimacy of institutions and authorities. In J. T. Jost \& B. Major (Eds.), The psychology of legitimacy: Emerging perspectives on ideology, justice, and intergroup relations (pp. 416-436). Cambridge: Cambridge University Press.

Tyler, T. R. (2006). Psychological perspectives on legitimacy and legitimation. Annual Review of Psychology, 57(1), 375-400. doi:10.1146/annurev. psych.57.102904.190038. 
Tyler, T. R., \& Caine, A. (1981). The influence of outcomes and procedures on satisfaction with formal leaders. Journal of Personality and Social Psychology, $41(4), 642$.

Tyler, T. R., \& Folger, R. (1980). Distributional and procedural aspects of satisfaction with citizen-police encounters. Basic and Applied Social Psychology, l(4), 281-292.

Tyler, T. R., \& Rasinski, K. (1991). Procedural justice, institutional legitimacy, and the acceptance of unpopular US Supreme Court decisions: A reply to Gibson. Law and Society Review, 25(3), 621-630.

Tyler, T. R., Rasinski, K. A., \& Spodick, N. (1985). Influence of voice on satisfaction with leaders: Exploring the meaning of process control. Journal of Personality and Social Psychology, 48(1), 72-81. doi:10.1037/00223514.48.1.72.

Van de Walle, S., \& Bouckaert, G. (2003). Public service performance and trust in government: The problem of causality. International Journal of Public Administration, 26(8-9), 891-913.

Van den Bos, K., Lind, E. A., Vermunt, R., \& Wilke, H. A. (1997). How do I judge my outcome when I do not know the outcome of others? The psychology of the fair process effect. Journal of Personality and Social Psychology, $72(5), 1034$.

Van den Bos, K., Wilke, H. A., Lind, E. A., \& Vermunt, R. (1998). Evaluating outcomes by means of the fair process effect: Evidence for different processes in fairness and satisfaction judgments. Journal of Personality and Social Psychology, 74(6), 1493.

Wallner, J. (2008). Legitimacy and public policy: Seeing beyond effectiveness, efficiency, and performance. Policy Studies Journal, 36(3), 421-443.

Weber, M. (1978). Economy and society: An outline of interpretive sociology. Berkeley, California: University of California Press. 


\title{
Interest Groups and Policy Capacity: Modes of Engagement, Policy Goods and Networks
}

\author{
Carsten Daugbjerg, Bert Fraussen and Darren Halpin
}

\subsection{INTRODUCTION}

Policy capacity has been defined as "the set of skills and resources-or competences and capabilities-necessary to perform policy functions" (Wu et al. 2015, p. 2), as well as the ability of states "to marshal the necessary resources to make intelligent choices about and set strategic directions for the allocation of scarce resources to public ends" (Painter and Pierre 2005 , p. 2). Policy capacity is also considered as the "weaving fabric" (Parsons 2004) necessary for the development of coherent policy and essential for policy success. In a similar vein, recent work has highlighted how governance arrangements can enable or constrain the capacity of governments to identify and address key policy problems, leading to policy success or the persistence of policy failures (Howlett et al. 2015).

While the concept of policy capacity usually has been applied at a 'systematic' level (such as at the aggregate level of governments or political systems), it can also be used to assess the resources and capabilities of organizations and individuals, and obtain a better understanding of their possible contribution to public policy. As argued by $\mathrm{Wu}$ et al., "the capacity of other stakeholders in policymaking is an important aspect of policy capacity" $(2015$, p. 3$)$. Other work has also noted the possible role of actors and organizations external to the government, such as experts, interest groups, non-profits and research organizations, in 
improving policy capacity (e.g. Peters 2015; May et al. 2016). Still, our knowledge of the resources and skills these external actors can contribute has remained rather limited so far.

In this chapter, we focus on the policy capacity of interest groups. More specifically, we explore which types of policy capacities interest groups may develop, as well as how the policy context and the relationships between governments and interest groups shape the generation and value of these capabilities. It is widely acknowledged that interest groups can play key roles in the policy process, in particular if they have generated their own group policy capacity through the possession of a number of 'policy goods' in the form of political and analytical skills, and resources and capabilities to assist in policy implementation. These 'policy goods' are highly valued by policymakers. While there has been an increasing understanding of the importance of the state's policy capacity, less attention has been focussed on how precisely it is generated within interest groups, the diversity of 'policy goods' they can provide, and organizational and contextual elements explaining variance in the potential of groups to contribute to policymaking. In this regard, Halpin (2014) highlights how the organizational design of a group is inherently connected to its ability to provide particular policy goods, while the value of these resources is also shaped by the demands of government, or by particular stages of the policy process, such as agenda setting, policy formulation or implementation. ${ }^{1}$ In other words, groups must make decisions as to how resources are deployed and invested. These decisions are embedded and evident in the organizational designs of groups, and represent sunk costs that are difficult to turn around. Not only do investments of resources create real capacities in certain things, they also foster a reputation for those abilities. Not all groups will likely have the abilities that policymakers see as useful. Hence, variation in their capacity should be anticipated. Some groups might, for instance, specialize in the provision of policy advocacy, while others might concentrate their efforts on policy implementation or the provision of services, or combine both activities, resulting in the development of different capabilities (Minkoff 2002; Marquez 2016). Indeed, referring back to Wu et al. (2015), we might even claim that groups could vary in their capacity with respect to political, operational and analytical skills. We return to this question later in the chapter.

While we can analyse the policy capacity of individual groups (and thus concentrate on the organizational level), we can also examine policy capacity in the specific policy context and in the context of the specific government-interest group relationship within a policy sector. That is, 
with the exception of cases in which interest groups are consulted in an ad hoc way, interaction between government and interest groups tends to proceed through policy networks. These can take various forms, ranging from tight and closed policy communities to loose and open issue networks, thus leading to variation in the type of capacities these networks can provide to policymakers. The former may, for instance, generate high levels of capacity to achieve output legitimacy, resulting in a high ability to form powerful coalitions with state actors but may suffer from low levels of input legitimacy. Issue networks, in contrast, may produce high levels of input legitimacy but be unable to agree on effective policies, rendering them a less powerful and more volatile resource for policymakers (Daugbjerg and Fawcett 2015).

In the first section of this chapter, we briefly review the literature on interest groups and public policy and consider how it relates to recent discussions on policy capacity. Subsequently, we demonstrate how the concept of policy capacity can be applied to interest groups, first at the organizational level and subsequently at the policy sector level. We develop the notion of policy capacity for both dimensions theoretically.

\subsection{The Interest Group and Public Policy Nexus}

It has been an established fact in political science and every-day politics that interest groups play a key role in public policymaking. Therefore, interest groups figure prominently in most public policy theories. However, the role that they perform in policymaking is disputed in the literature. The classical pluralist interest group literature growing out of Truman's (1951) work had a positive view, arguing that interest groups aggregated and articulated the preferences of various groups in society. Unlike later interest group theories, classical pluralism was not concerned about concentration of power in the hands of a few privileged groups. It was argued that the distribution of power in a society would be fairly equal because the interest group system had mechanisms which would ensure that the system would continuously move towards an equilibrium. Overlapping memberships of interest groups, counter mobilization of unorganized groups, counter-balancing by government actors and not least the view that many types of resources count in policymaking would ensure that no single group would dominate policymaking.

Olson's (1965) seminal work questioned this pluralist view, arguing that interest groups are rent seekers mainly concerned about achieving 
as many benefits and privileges as possible for their members by utilizing their opportunities for collective action. Interest groups representing well-defined groups with particularistic preferences and major stakes in a policy would more easily and successfully mobilize than broader groups representing more diffuse interests. Olson's work laid the foundation of the public choice school in interest group studies. This school shared with classical pluralism the assumption that the main role of interest groups was to aggregate and articulate the preferences of their members. Saliently for our purposes, Olson's remedy was not the proliferation of more and more groups as pluralists envisaged, but rather the rationalization of the group system into a small number of 'encompassing groups' (Olson 1982). A key feature of such groups was that they incorporated broad sections of society sufficient to incorporate winners and losers. This was assumed to guard against claims that were overly narrow and self-interested.

Neo-corporatist theory challenged this assumption, arguing that interest groups, or rather interest associations, performed roles going far beyond aggregating and articulating preferences (for a good overview, see Williamson 1989 or Streeck and Kenworthy 2005). Their main role in policymaking was to intermediate between the interests of the members and that of the state. They were seen as integrated in the political system and deeply involved in the policy formulation and implementation process, and capable of disciplining their members to comply with negotiated policy compromises agreed between state officials and leaders of the interest associations. In some situations they even performed regulatory roles on behalf of the state by being delegated authority to implement policy. Corporatists depicted this phenomenon as 'private interest governments'.

More contemporary approaches to interest groups and policymaking might usefully be referred to as neo-pluralist (Lowery and Gray 2004; McFarland 2007). This is a loosely coherent literature, which sharescompared to early 'naïve' pluralism-heightened sensitivity to the likelihood of 'bias' in the mobilization of different types of interests and routinely reports the numerical dominance of business in political arenas and contests. There is also an awareness of the role that variations in resources among groups have on their potential to gain access to government and ultimately to shape policy outcomes. The notion that groups themselves hold or develop certain organizational capacities has been explored in a limited manner (Bouwen 2004; Hall and Deardorf 2006; Maloney et al. 1994). More recently, this has started to be discussed 